\title{
Astımlı Çocuklarda COViD-19 Pandemisi Döneminde Astım Kontrolü ve Anksiyete Düzeyinin Değerlendirilmesi
}

\section{Evaluation of Asthma Control Status and Anxiety Level During the COVID-19 Pandemic in Children with Asthma}

\author{
Betül KARAATMACA ${ }^{1}$, Ahmet SELMANOĞLU1', Tayfur GiNiŞ ${ }^{1}$, Esra ÇÖP², Gülser ŞENSES DINÇ², \\ Özden Şükran ÜNERi ${ }^{2}$, Müge TOYRAN ${ }^{1}$, Ersoy CIVELEK ${ }^{1}$, Emine DIBBEK MISIRLIOĞLU ${ }^{1}$
}

'SBÜ, Ankara Şehir Hastanesi, Çocuk Hastanesi, Çocuk Alerji ve İmmünoloji Kliniği, Ankara, Türkiye

22SBÜ, Ankara Şehir Hastanesi, Çocuk Hastanesi, Çocuk ve Ergen Ruh Sağlığı ve Hastalıkları Kliniği, Ankara, Türkiye

\section{Öz}

Amaç: Çalışmamızda astımlı çocuklarda ve ailelerinde yeni tip coronavirüs hastalığı (COVID-19) döneminde astım kontrol durumları, ilaç uyumları ve kaygı düzeylerinin değerlendirilmesi amaçlanmıştır.

Gereç ve Yöntemler: Çalışmaya en az altı aydır astım tanısıyla izlenen 8-12 yaş arası 67 çocuk ve ebeveynleri dahil edilmiştir. Ebeveynlere yaş, cinsiyet, astım ilaçları gibi demografik özellikleri ve 5'li Likert ölçeğine göre hazırlanmış COVID-19 ile ilgili soruları içeren anket yapılmıştır. Ayrıca çocukluk çağı astım kontrol anketi (AKT) ve kaygı düzeyini değerlendirmek için çocuklara Çocuklar İçin Durumluk-Sürekli Kaygı Envanteri (Ç-DSKE), ebeveynlere de Erişkinler için Durumluk-Sürekli Kaygı Envanteri (DSKE) uygulanmıştır.

Bulgular: Hastaların ortalama yaşı 9.5 \pm 1.2 yıl, astım takip süresi ortancası (çeyrekler arası aralık) 36 (21-66) aydı ve 45’i (\%67.2) erkekti. Çocukların çoğu astım ilaçlarını düzenli kullanıyordu. Çocukların Ç-DSKE durumluk ve sürekli kaygı puanları, ebeveynlerin DSKE durumluk ve süreklik kaygı puanlarıla istatistiksel olarak anlamlı pozitif yönde korelasyon gösteriyordu. Hastalığı geçireceğini, COVID-19'a karşı etkili tedavi ve aşı bulunamayacağını düşünen ebeveynlerin kaygı düzeyleri daha yüksek bulundu. Çocukların cinsiyeti, astım takip süreleri, astım kontrol durumları, düzenli takibe gelme ve astım ilacını düzenli kullanmasına göre gruplandırılarak karşılaştıııdığında yine çocuk Ç-DSKE ve ebeveynlerin DSKE skorları arasında fark yoktu.

Sonuç: Pandemi döneminde düzenli kontrol ve ilaç uyumu çocuklarda astım semptomlarının kontrol altına alınmasında son derece önemlidir. Astımlı çocuklarda pandeminin etkileri de göz önünde bulundurularak poliklinik kontrolleri sırasında psikososyal değerlendirilmelerinin yapılması çocukların ruh sağlığı ve hastalık kontrolü üzerinde olumlu etkileri olabilir.

Anahtar Sözcükler: Astım, COVID-19, Çocuk, Kaygı, Pandemi

ABSTRACT

Objective: We aimed to evaluate asthma control status, drug compliance and anxiety levels of children and their parents who were followed up with the diagnosis of asthma during the COVID-19 pandemic.

Material and Methods: Sixty-seven children aged between 8-12 years diagnosed with asthma and their parents were prospectively recruited to the study. A questionnaire including demographic features such as age, gender, asthma

(i)

KARAATMACA B

SELMANOĞLU A

GiNiș T

ÇÖPE

ŞENSES DINÇ G

ÜNERI ÖȘ

TOYRAN M

CIVELEKE

DIBEK MISIRLIOĞLU E
0000-0002-8383-6350 $0000-0002-6748-7330$ 0000-0003-1939-3951 0000-0001-8451-0099 0000-0001-5556-3175 0000-0002-7869-5338 0000-0002-2490-0551 0000-0002-1780-4801 : 0000-0002-3241-2005
Çıkar Çatışması / Conflict of Interest: Tüm yazarlar adına, ilgili yazar çıkar çatıșması olmadığııı belirtir.

Etik Kurul Onayı / Ethics Committee Approval: Bu çalıșma Helsinki Deklarasyonu İlkelerine uygun olarak yapılmıştır. Çalıșma katıımcılarından çalışma hakkında bilgilendirilerek onamları ve Ankara Şehir Hastanesi etik kurulundan da çalışma onayı alınmıştır (28.05.2020/689).

Yazarların katkısı / Contribution of the Authors: KARAATMACA B: Sonuçlara ulașmak için planlama/metodoloji belirleme, Araștırma/çalıșmanın sorumluluğunu üstlenmek, ilerlemenin seyrini denetlemek, Hasta takibinde sorumluluk almak, ilgili biyolojik malzemelerin toplanması, veri yönetimi ve raporlama, deneylerin yürütülmesi, Sonuçların mantıksal olarak Yorumlanması ve sonuçlandırıması, Çalışma için gerekli literatür taramasında sorumluluk almak, Çalıșmanın bütününün veya önemli bölümlerinin yazımında sorumluluk almak, Yazım ve dilbilgisi dıșında bilimsel olarak gönderilmeden önce makaleyi gözden geçirme. SELMANOĞLU A: Çalışma için gerekli literatür taramasında sorumluluk almak. GiNiş T: Hasta takibinde sorumluluk almak, ilgili biyolojik malzemelerin toplanması, veri yönetimi ve raporlama, deneylerin yürütülmesi, Çalışma için gerekli literatür taramasında sorumluluk almak. ÇOP E: Sonuçlara ulaşmak için planlama/metodoloji belirleme, Hasta takibinde sorumluluk almak, ilgili biyolojik malzemelerin toplanması, veri yönetimi ve raporlama, deneylerin yürütülmesi. ŞENSES DiNÇ G: Sonuçlara ulaşmak için planlama/metodoloji belirleme, Çalısma için gerekli literatür taramasında sorumluluk almak. ÜNERI ÖȘ: Sonuçlara ulașmak için planlama/metodoloji belirleme. TOYRAN M: Araștırma/çalıșmanın sorumluluğunu üstlenmek, ilerlemenin seyrini denetlemek, Sonuçların mantıksal olarak Yorumlanması ve sonuçlandırılması, Yazım ve dilbilgisi dıșında bilimsel olarak gönderilmeden önce makaleyi gözden geçirme. CiVELEK E: Araștırma/çalıșmanın sorumluluğunu üstlenmek, ilerlemenin seyrini denetlemek, Hasta takibinde sorumluluk almak, ilgili biyolojik malzemelerin toplanması, veri yönetimi ve raporlama, deneylerin yürütülmesi, Yazım ve dilbilgisi dışında bilimse olarak gönderilmeden önce makaleyi gözden geçirme. DiBEK MISIRLIOĞLU E: Araştırma ve/veya makalenin hipotezini veya fikrini oluşturan, Sonuçlara ulaşmak için planlama/metodoloji belirleme, Araşııma/çalışmanın sorumluluğunu üstlenmek, ilerlemenin seyrini denetlemek, Sonuçların mantıksal olarak Yorumlanması ve sonuçlandırılması, Yazım ve dilbilgisi dıșında bilimsel olarak gönderilmeden önce makaleyi gözden geçirme.

Atıf yazım şekli / How to cite : Karaatmaca B, Selmanoğlu A, Giniș T, Çöp E, Şense Dinç G, Üneri ÖȘ ve ark. Astımlı Çocuklarda COViD-19 Pandemis Döneminde Astım Kontrolü ve Anksiyete Düzeyinin Değerlendirilmesi. Türkiye Çocuk Hast Derg 2021;15:386-393.
Yazıșma Adresi / Correspondence Address:

\section{Betül KARAATMACA}

Ankara Sehir Hastanesi, Çocuk Hastanesi,

Çocuk Alerji ve Immünoloji Kliniği, Ankara, Türkiye

E-posta: drbkatmaca@gmail.com
Geliş tarihi/ Received : :23.06.2021 Kabul tarihi / Accepted : 10.08.2021 Elektronik yayın tarihi : 10.09.2021 Online published

DOI: 10.12956/tchd.956354 
medications and questions about COVID-19 prepared according to a 5-point Likert scale was conducted to the parents. Children completed the State-Trait Anxiety Inventories for Children (STAI-C) scales, and childhood asthma control test(c-ACT). Parents also fulfilled STAl scales.

Results: The mean age of the patients was 9.5 \pm 1.2 years, the median follow-up period for asthma (C-ACT) was 36 (21-66) months, and 45 (67.2\%) were male. Most of the children were using their asthma medication regularly. Children's STAI-C state and trait anxiety scores showed a statistically significant positive correlation with parents' STAI state and trait anxiety scores. The anxiety levels of parents who thought that they would get the disease and that there would be no effective treatment and vaccine against COVID-19 were found to be higher.

Conclusion: During the pandemic period, regular asthma follow-up and drug compliance are very important controlling asthma symptoms in children. Considering the effects of the pandemic in children with asthma, psychosocial evaluations during outpatient controls may have positive effects on children's mental health and disease control.

Key Words: Anxiety, Asthma, Child, COVID-19, Pandemic

\section{GiRiş}

Astım çocukluk çağının en sık görülen kronik solunum yolu hastalıklarından birisidir (1). Etiyolojisinde hem genetik hem çevresel etmenlerin rol oynadığı, hava yollarının geri dönüşümlü obstrüksiyonu, bronş aşırı duyarlıı̆̆ı ve kronik enflamasyonla seyreden bir hastalıktır (2). Astım klinik olarak farklı fenotiplerden oluşmaktadır, hastalığın seyri remisyon ve akut alevlenmelerle karakterizedir. Alerjenler, sigara ve viral enfeksiyonlar astım ataklarının en önemli tetikleyicileridir (3).

Yeni tip koronavirüs hastalığı (COVID-19), 11 Mart 2020'de Dünya Sağlık Örgütü tarafından pandemi olarak ilan edilmiş ve etkeni şiddetli akut solunum sendromu coronavirüs-2 (SARSCoV-2) olarak adlandırımıştır (4). Klinik bulgular asemptomatik enfeksiyondan, hafif üst solunum yolu enfeksiyonu bulguları, pnömoni ve akut ciddi solunum yetmezliği hatta ölüme kadar geniş bir spektrumda görülebilir (5). Çocuklarda COVID-19 enfeksiyonu erişkinlere göre daha hafif seyrettiği çalışmalarda bildirilmiştir. Ancak Kawasaki Sendromu'na benzer semptomların eşlik ettiği daha ağır semptomlarla seyreden çocuklarda multisistem enflamatuar sendromu daha sonradan tanımlanmıştır $(6,7)$.

Astım gibi kronik solunum yolu hastalıkları olanlar COVID-19 enfeksiyonuna yatkınlık için potansiyel riske sahiptirler (8). Viral solunum yolu enfeksiyonlarından rinovirüsler astım atakları ile yakından ilişkiliyken, koronavirüsler nispeten daha az suçlanan tetikleyicilerdendir (9). Ancak astımlılarda COVID-19 enfeksiyonu seyri konusunda çalışmalarda farklı bulgular bildirilmiştir. Bazı çalışmalarda astım varlığıyla COVID-19 enfeksiyonu arasında ilişkili bulunmamışken, bazı çalışmalarda ise astım varlığının COVID-19 enfeksiyonu sonucu hastane ölümlerini arttırdığı bildirilmiştir (10-12). Bu konuda daha fazla araștırmaya intiyaç vardır.

Pandeminin başlangıcındaki belirsizlikler, hastaneye başvurularda viral bulaş riski, pandeminin ekonomik ve sosyal etkileri toplumda kaygı ve endişeye yol açmışıı (13). Okulların kapanmasının, uzaktan eğitimin ve uzun süreli kapanmaların gençler ve çocukların ruhsal sağlığı üzerinde olumsuz etkileri olmuştur (14).

Astım kontrolünün en iyi şekilde yapılabilmesi için astım tedavisine uyum şarttır. Çalışmalarda iyi astım kontrolünün astımlı çocukların hayat kalitesi skorlarını iyileştirdiği gösterilmiştir
$(15,16)$. Anksiyete bozukluğu, Türk çocukları arasında en yaygın psikiyatrik bozukluklardan biridir $(17,18)$. Stresli yaşam olayları, sağlık sorunları ve aşırı internet kullanımı gibi etmenler çocukların ruh sağlığını olumsuz olarak etkileyebilir. Pandeminin etkilerinin yanı sıra astımlılarda genel topluma kıyasla daha fazla depresyon ve anksiyete semptomlarına sahip olduğu, ayrıca bu bulguların zayıf astım kontrolü ve ilaç uyumuyla ilişkili olduğu bildirilmiştir (2).

Çalışmamızda bulaştırıcılığı son derece yüksek olan, tüm dünyaya hızla yayılan ve solunum yollarının öncelikli olarak etkilendiği COVID-19 pandemisinde astımlı çocukların astım kontrol durumlarının ve ilaç uyumlarının değerlendirilmesi ile pandeminin astımlı çocuklar ve ebeveynlerinin anksiyeteleri üzerine etkilerinin değerlendirilmesi amaçlanmıştır.

\section{GEREÇ ve YÖNTEMLER}

Çalışmamıza Ankara Şehir Hastanesi, Çocuk Alerji ve İmmünoloji kliniğimizde Haziran-Kasım 2020 tarihleri arasında, Global Initiative for Asthma (GINA) (2) kllavuzuna göre en az altı aydır astım tanısıyla izlenen 8-12 yaş arası çocuklar ve ebeveynleri prospektif olarak dahil edilmiştir. Hastaların anketleri rutin poliklinik kontrolleri sırasında yüz yüze olarak yapılmıştır. Hastaların yaş, cinsiyet, astım kontrolü açısından durumları, atopi durumları, ailenin gelir düzeyi, ebeveynlerin eğitim durumu, astım ilaçları ve kullanımı gibi demografik özellikleri sorularak çalışma formuna kaydedilmiştir. Ayrıca ebeveynlere COVID-19 enfeksiyonu ile düşüncelerini soran 5'li Likert ölçeğine göre hazırlanmış (Kesinlikle katılmıyorum/ Katılmıyorum/ Kararsızım/ Katılyorum/ Kesinlikle katılyorum) 17 soruluk mini anket uygulanmıştır. Anketin içeriğinde ebeveynlere COVID-19 enfeksiyonuna yakalanma, așı, tedavi, koruyucu önlemler ve astım ile ilişkisini değerlendiren sorular sorulmuştur. Ayrıca katılanlar grubuna "Kesinlikle katıliyorum/Katılıyorum" yanıtı verenler, katımayanlar grubuna ise "Kesinlikle katımıyorum/ Katımıyorum/Kararsızım" yanıtını verenler dahil edilerek 2 gruba ayrımış ve gruplar arası anksiyete skorlarının karşılaşııııımaları yapılımışıtır.

Psikiyatrik hastalığı ve alerjik hastalıklar dışında kronik hastalığı olan çocuklar ile psikiyatrik hastalığı olan ebeveynler klinik skorlamaların etkilenmemesi için çalışma dışı bırakıldı. 


\section{Çocukluk Çağı Astım Kontrol Testi}

Anket, astım semptomlarını, astımın günlük yaşama etkisini ve son 4 hafta içinde kurtarıcı ilaç intiyacını değerlendiren 7 maddeden oluşmaktadır. Maddelere verilen yanıtlar 1 ile 5 arasında değişmektedir, Sorulara verilen yanıtlar çocuklarda 0 ile 3 puan, ebeveynlerde ise 0 ile 5 puan arasında değișmektedir ve düşük puanlar kötü astım kontrolü ile uyumludur. Illk 4 soru çocuk tarafindan, son 3 soru ebeveyn tarafindan cevaplanmaktadır. Anketin Türkçe validasyonu yapıımıştır, 19 puan ve altı astımın yeterince kontrol altında olmadığını, 20 puan ve üstü iyi astım kontrolünü düşündürmektedir $(19,20)$.

\section{Çocuklar Için Durumluk-Sürekli Kaygı Envanteri}

Çocuklar için Durumluk-Sürekli Kaygı Envanteri (Ç-DSKE), her biri 20 maddelik iki alt ölçekten oluşan toplam 40 maddelik, çocukların durumluk ve süreklilik kaygı düzeylerini kendi bildirimlerine göre değerlendiren Türkçe validasyonu yapılmış olan bir ölçektir. Durumluk kaygı düzeyi belirli koșullar altındaki bireyin kaygı düzeylerini ve sürekli kaygı düzeyi ise kişinin doğuştan gelen genel kaygı düzeyini değerlendirmektedir. Yüksek puanlar, yüksek kaygı düzeyini gösterir $(21,22)$.

\section{Erişkinler için Durumluk-Sürekli Kaygı Envanteri}

Erişkinler için Durumluk-Sürekli Kaygı Envanteri (DSKE-1 ve DSKE-2), her biri 20 maddeden oluşan iki alt ölçekten oluşan toplam 40 maddelik Türkçe validasyonu yapılmış olan bir ölçektir. Ölçek kişinin kendi bildirimlerine göre hem belirli koşullar altındaki durum kaygısını (DSKE-1) hem de genel kaygı düzeyini (DSKE-2) ölçmek için kullanılabilir. Yüksek puanlar, yüksek kaygı düzeyini gösterir $(23,24)$.

\section{İstatistiksel Analizler:}

Çalışmamızda Veriler, SPSS 22 programında analiz edildi. Tanımlayııı istatistikler; kategorik değişkenler için sayı ve yüzde, sayısal değişkenler için verilerin dağılımına göre ortalama, standart sapma, ortanca 25. ve 75. persantil, çeyrekler arası aralık olarak verildi. Sürekli değișkenler arasında anlamlı fark bulunup bulunmadığı karşılaştıılan grupların sayısına ve verilerin normal dağllip dağılmadığına uygun olarak non-parametrik testlerden Kruskal Wallis ve Mann Whitney U testleri, parametrik testlerden ise Independent Samples T Testi ve One Way Anova testleri kullanılarak analiz edilmiştir. Korelasyon analizleri verilerin dağlımına göre Pearson veya Spearman testiyle yapıımıştır. $p<0.05$ değeri istatistiksel anlamlı kabul edildi.

Çalışma katılımcılarından çalışma hakkında bilgilendirilerek onamları ve Ankara Şehir Hastanesi etik kurulundan da çalışma onayı alınmıştır (28.05.2020/689).

\section{BULGULAR}

Çalışmamıza yaşları 8-12 yll arasında olan toplam 67 astım hastası çocuk ve ebeveyni dahil edildi, hastaların 45'i (\%67.2) erkekti. Hastaların ortalama yaşı $9.5 \pm 1.2$ yıl ve astım takip süresi
Tablo I: Hastaların demografik özellikleri

\begin{tabular}{|c|c|}
\hline & $\begin{array}{c}\text { Çalışma } \\
\text { popülasyonu } \\
(n=67)\end{array}$ \\
\hline Yaş (yıl) * & $9.5( \pm 1.2)$ \\
\hline Cinsiyet. n. Erkek/Kız (Erkek \%) & 45/22 (67.2) \\
\hline Anketi dolduran ebeveynin yaşı † & $36.5( \pm 6.7)$ \\
\hline Anketi dolduran. Anne/Baba (Anne \%) & $56 / 11(83.6)$ \\
\hline Astım takip süresi (ay) ${ }^{\dagger}$ & $36(21-66)$ \\
\hline Astım takibine düzenli gelenler ${ }^{\ddagger}$ & $55(82.1)$ \\
\hline Astım ilacını düzenli kullananlar $\ddagger$ & $57(85.1)$ \\
\hline $\begin{array}{l}\text { GINA'ya astım tedavisi } \\
\text { Basamak } 1 .{ }^{\ddagger} \\
\text { Basamak 2. }{ }^{\ddagger} \\
\text { Basamak } 3 .{ }^{\ddagger}\end{array}$ & $\begin{array}{r}8(11.9) \\
36(53.7) \\
23(34.3)\end{array}$ \\
\hline $\begin{array}{l}\text { Son } 1 \text { yılda } \neq \\
\text { Astım nedeniyle hastaneye yatışı olanlar } \\
\text { Sistemik steroid gerektiren astım atağı olanlar } \\
\text { Astıma bağlı yoğun bakım yatışı olanlar } \\
\text { Astıma bağlı acil servis başvurusu olanlar } \\
\text { Hiç } \\
1-2 \mathrm{kez} \\
>3 \mathrm{kez}\end{array}$ & $\begin{array}{c}3(4.5) \\
5(8.2) \\
0 \\
49(73.1) \\
12(17.9) \\
9(9)\end{array}$ \\
\hline $\begin{array}{l}\text { Son } 4 \text { hafta içinde } \\
\text { Gündüz astım semptomları haftada ikiden fazla olanlar } \\
\text { Gece astım semptomları haftada ikiden fazla olanlar } \\
\text { Haftada iki defadan fazla KEBA kullananlar } \\
\text { Astıma bağlı aktivite kısıtıı̆ı olanlar }\end{array}$ & $\begin{array}{l}14(20.9) \\
12(17.9) \\
10(14.9) \\
14(20.9)\end{array}$ \\
\hline $\begin{array}{l}\text { GINA'ya göre astım semptom kontrolü } \\
\text { lyi kontrollü }{ }^{\ddagger} \\
\text { Kısmi kontrollü }{ }^{\ddagger} \\
\text { Kontrolsüz }{ }^{\ddagger}\end{array}$ & $\begin{array}{l}46(68.7) \\
11(16.4) \\
10(14.9)\end{array}$ \\
\hline Çocukluk çağı AKT puanı * & $24(19-25)$ \\
\hline $\begin{array}{l}\text { Çocukluk çağı AKT puanına göre astım kontrolü } \\
\text { lyi kontrollü }{ }^{\ddagger} \\
\text { Kontrolsüz }{ }^{\ddagger}\end{array}$ & $\begin{array}{l}57(85.1) \\
10(14.9)\end{array}$ \\
\hline $\begin{array}{l}\text { Annenin eğitim düzeyi } \\
\text { Illkokul } \\
\text { Ortaokul } \ddagger \\
\text { Lise }^{\ddagger} \\
\text { Lisans }^{\ddagger} \\
\text { Yüksek Lisans-Doktora }{ }^{\ddagger}\end{array}$ & $\begin{array}{c}19(28.4) \\
16(23.9) \\
18(26.8) \\
13(19.4) \\
1(1.5)\end{array}$ \\
\hline $\begin{array}{l}\text { Babanın eğitim düzeyi } \\
\text { Illkokul }{ }^{\ddagger} \\
\text { Ortaokul }{ }^{\ddagger} \\
\text { Lise }^{\ddagger} \\
\text { Lisans }^{\ddagger}\end{array}$ & $\begin{array}{l}12(17.9) \\
11(16 .) \\
36(53.7) \\
8(11.9)\end{array}$ \\
\hline $\begin{array}{l}\text { Ailenin aylık geliri } \\
<1500 \mathrm{TL} \ddagger \\
1500-3000 \mathrm{TL} \ddagger \\
>3000 \mathrm{TL} \ddagger\end{array}$ & $\begin{array}{r}8(11.9) \\
26(38.8) \\
33(49.3)\end{array}$ \\
\hline Atopi varlığı $\neq$ & $30(44.8)$ \\
\hline Eşlik eden atopik hastalık $\ddagger$ & $39(58.2)$ \\
\hline Ailede atopik hastalık $\ddagger$ & $21(31.3)$ \\
\hline
\end{tabular}

*: ortalama (standart sapma), ': ortanca (çeyreklerarası aralık); *: n(\%), AKT: Astım kontrol anketi, GINA: Global Initiative for Asthma, TL: Türk Lirası, KEBA: Kısa etkili beta agonist 
Tablo II: Ebeveynlerin COVID-19 anketine yanıtları.

\begin{tabular}{|c|c|c|c|c|c|}
\hline & $\begin{array}{c}\text { Kesinlikle } \\
\text { katılmıyorum } \\
\mathrm{n}(\%)\end{array}$ & $\begin{array}{l}\text { Katılmiyorum } \\
\text { n (\%) }\end{array}$ & $\begin{array}{l}\text { Kararsızım } \\
\text { n (\%) }\end{array}$ & $\begin{array}{l}\text { Katilıyorum } \\
\text { n (\%) }\end{array}$ & $\begin{array}{l}\text { Kesinlikle } \\
\text { katılıyorum } \\
\text { n (\%) }\end{array}$ \\
\hline \multicolumn{6}{|l|}{ Koronavirüs enfeksiyonuna } \\
\hline Yakalanacağınıza ne kadar inanıyorsunuz? & $10(14.9)$ & $18(26.9)$ & $19(28.4)$ & $12(17.9)$ & $8(11.9)$ \\
\hline Aileden birinin yakalanacağına ne kadar inanıyorsunuz? & $9(13.4)$ & $19(28.4)$ & 21 (31.3) & $11(16.4)$ & 7 (10.4) \\
\hline Yakalanırsanız iyileșeceğinize ne kadar inanıyorsunuz? & $3(4.5)$ & $4(6)$ & $19(28.4)$ & 18 (26.9) & $23(34.3)$ \\
\hline Aile biri yakalanırsa iyileșeceğine ne kadar inanıyorsunuz? & $2(3)$ & $4(6)$ & 18 (26.9) & $23(34.3)$ & $20(29.9)$ \\
\hline \multicolumn{6}{|l|}{$\begin{array}{l}\text { Koronavirüs enfeksiyonunu } \\
\text { Tedavi eden ilaç bulunacağına ne kadar ina }\end{array}$} \\
\hline Önleyecek aşı bulunacağına ne kadar inanıyorsunuz? & $10(14.9)$ & $8(11.9)$ & $13(19.4)$ & $12(17.9)$ & $24(35.8)$ \\
\hline Önleyecek aşı bulunursa kendinize yaptırmayı düşünüyor & $8(11.9)$ & $9(13.4)$ & $12(17.9)$ & $12(17.9)$ & $26(38.8)$ \\
\hline musunuz? & $6(9)$ & $1(1.5)$ & $15(22.4)$ & $11(16.4)$ & $34(50.7)$ \\
\hline $\begin{array}{l}\text { Önleyecek aşı bulunursa çocuğunuza aşı yaptırmayı düşünüyor } \\
\text { musunuz? }\end{array}$ & $6(9)$ & $2(3)$ & $18(26.9)$ & $8(11.9)$ & $33(49.3)$ \\
\hline \multicolumn{6}{|l|}{ Koronavirüs enfeksiyonundan korunmada } \\
\hline $\begin{array}{l}\text { El yikamanın ne kadar koruyucu olduğunu düșünüyorsunuz? } \\
\text { Sosyal izolasyonun ne kadar koruyucu olduğunu } \\
\text { düsünüyorsunuz? }\end{array}$ & $\begin{array}{l}2(3) \\
2(3)\end{array}$ & $\begin{array}{l}1(1.5) \\
2(3)\end{array}$ & $\begin{array}{l}3(4.5) \\
6(9)\end{array}$ & $\begin{array}{c}9(13.4) \\
12(17.9)\end{array}$ & $\begin{array}{l}52(77.6) \\
45(67.2)\end{array}$ \\
\hline $\begin{array}{l}\text { Sosyal mesafenin korunmasının ne kadar koruyucu olduğunu } \\
\text { düșünüyorsunuz? }\end{array}$ & $2(3)$ & $0(0)$ & $6(9)$ & $12(17.9)$ & $47(70.1)$ \\
\hline $\begin{array}{l}\text { Maske takmanın ne kadar koruyucu olduğunu } \\
\text { düşünüyorsunuz? }\end{array}$ & $1(1.5)$ & $2(3)$ & $7(10.4)$ & $20(29.9)$ & $37(55.2)$ \\
\hline \multicolumn{3}{|l|}{ Koronavirüs enfeksiyonuyla ilgili haberlerde } & $20(29.4)$ & $16(23.9)$ & $8(11.9)$ \\
\hline $\begin{array}{l}\text { Sosyal medya takibiyle bilgi sahibi olduğunuzu düşünüyor } \\
\text { musunuz? }\end{array}$ & $6(9)$ & $6(9)$ & $15(22.4)$ & $30(44.8)$ & $10(14.9)$ \\
\hline \multicolumn{6}{|l|}{ Koronavirüs hastalığında astımın } \\
\hline $\begin{array}{l}\text { Yakalanmada daha riskli olduğunu düşünüyor musunuz? } \\
\text { Tedavisini zorlaştırdığını düşünüyor musunuz? }\end{array}$ & $\begin{array}{l}3(4.5) \\
4(6)\end{array}$ & $\begin{array}{l}8(11.9) \\
5(7.5)\end{array}$ & $\begin{array}{l}13(19.4) \\
7(10.4)\end{array}$ & $\begin{array}{l}21(31.3) \\
28(41.8)\end{array}$ & $\begin{array}{l}22(32.8) \\
23(34.8)\end{array}$ \\
\hline \multicolumn{6}{|l|}{ Hastaneye gelirken toplu taşıma kullanıyorsanız } \\
\hline Koronavirüs bulașması için ne kadar riskli buluyorsunuz? & $6(9)$ & $6(9)$ & $13(19.4)$ & $22(32.8)$ & 20 (29.9) \\
\hline
\end{tabular}

ortancası (çeyrekler arası aralık) 36 (21-66) aydı. Anketi dolduran ebeveynlerin ortalama yaşı $36.5 \pm 6.7 \mathrm{yll}$, anketi dolduranların 56 'sı (\%83.6) annelerdi.

Astımlı hastaların çoğu takiplerine düzenli geliyordu (\%82.1) ve ilaçlarını düzenli kullanıyordu (\%85.1). Çocukluk çağı AKT puanlarına göre hastaların \%85.1'i iyi kontrollü olarak sınıflandıııldı. Çalıșmamızdaki astımlı çocukların hiçbirinde başvuru sırasında COVID-19 enfeksiyonu ile ilişkili semptomları ve şikayetleri yoktu. Ayrıca astımlı çocuklardan hiçbirinde veya ailesinde daha önce COVID-19 geçirme öyküsü yoktu. Hastaların demografik özellikleri Tablo l'de özetlenmiştir.

Cinsiyete, atopi durumuna, kardeș sayısına, ailenin ayllk geliri ve eșlik eden başka atopik hastalığın olup olmamasına göre karşılaştıııldığında çocukların Ç-DSKE ya da ebeveynlerin DSKE skorları arasında fark saptanamadı ( $p>0.05)$. Ayrıca çocuklar astım takip süreleri, astım kontrol durumları, düzenli takibe gelme ve astım ilacını düzenli kullanmasına göre gruplandırılarak karşılaştııılı̆ğında yine çocuk Ç-DSKE ya da ebeveynlerin DSKE skorları arasında fark yoktu ( $p>0.05)$.
Çocukların C-DSKE durumluk skoru ortalama $31.87 \pm 7.43$, sürekli skoru ortalama $34.72 \pm 6.22$ olarak bulundu. Ebeveynlerin DSKE-1 skoru ortalaması 38.66 \pm 9.69 , DSKE-2 skoru ortalaması ise $42.88 \pm 8.66$ 'dı. Çocukların Ç-DSKE durumluk ve sürekli kaygı puanları, ebeveynlerin DSKE durumluk ve süreklik kaygı puanlarıla istatistiksel olarak anlamlı pozitif yönde korelasyon gösteriyordu (Şekil 1A-D).

Ebeveynlere 5'li Likert ölçeğine göre hazırlanmış COVID-19 enfeksiyonuna karșı bilgi ve tutumlarını sorgulayan 17 soruluk mini anket uygulandı. Ankette ebeveynlerin çoğu așı geliștirilmesi durumunda kendisine ve çocuğuna aşı yaptıracağını, koronavirüs enfeksiyonundan korunmada el yıkama, sosyal izolasyon, sosyal mesafe ve maske kullanımının koruyucu olduğunu düşündüğünü bildirdi. Ayrıca çoğu ebeveyn astımın hem koronavirüs enfeksiyonuna yakalanmada hem de tedavide güçlük oluşturduğunu düşünüyordu. Anket sonuçları Tablo I'de özetlenmiştir.

Ebeveynlere 5'li Likert ölçeğindeki sorulara verdikleri yanıtlara göre katılanlar ve katımayanlar olarak iki gruba ayrlarak DSKE durum ve sürekli kaygı puanları karşılaştıııldığında 
Tablo III: Ebeveynlerin COVID-19 anketine yanıtlarına göre DSKE-1 ve DSKE-2 skorlarııı karşılaştıılması.

\begin{tabular}{|c|c|c|c|c|}
\hline & $\begin{array}{l}\text { Katılmayanlar } \\
\text { DSKE 1- DSKE } 2\end{array}$ & $\mathbf{p}$ & $\begin{array}{c}\text { Katılanlar } \\
\text { DSKE 1- DSKE } 2\end{array}$ & $\mathbf{p}$ \\
\hline \multicolumn{5}{|l|}{ Koronavirüs enfeksiyonuna } \\
\hline Yakalanacağınıza ne kadar inanıyorsunuz? & $36(31-41)-41(36-46)$ & 0.009 & $43(36-50.5)-45(40.25-55)$ & 0.026 \\
\hline $\begin{array}{l}\text { Aileden birinin yakalanacağına ne kadar } \\
\text { inanıyorsunuz? }\end{array}$ & $36(31-42)-41(36-46.5)$ & 0.025 & $41.5(35.5-49.5)-45(39.75-55.5)$ & 0.05 \\
\hline $\begin{array}{l}\text { Yakalanırsanız iyileşeceğinize ne kadar } \\
\text { inanıyorsunuz? }\end{array}$ & 39 (33.25-48.75) - 44 (38.75-49.25) & 0.117 & $36(32-41)-43(34.5-47)$ & 0.35 \\
\hline $\begin{array}{l}\text { Aile biri yakalanırsa iyileşeceğine ne kadar } \\
\text { inanıyorsunuz? }\end{array}$ & $40(36-50.25)-44.5(39.25-50.5)$ & 0.014 & $36(31-41)-42(36-47)$ & 0.113 \\
\hline $\begin{array}{l}\text { Koronavirüs enfeksiyonunu } \\
\text { Tedavi eden ilaç bulunacağına ne kadar } \\
\text { inanıyorsunuz? }\end{array}$ & $42(36-48)-46(39-53)$ & 0.013 & $35.5(31.25-39)-40.5(36-44)$ & 0.011 \\
\hline Önleyecek aşı bulunacağına ne kadar inanıyorsunuz? & $44(36-48.5)-46(38-53.5)$ & 0.01 & $35.5(31-39.5)-41(36-44.25)$ & 0.04 \\
\hline $\begin{array}{l}\text { Onleyecek aşı bulunursa kendinize yaptırmayı } \\
\text { düşünüyor musunuz? }\end{array}$ & $37.5(33.75-46.25)-40.5(32.5-46.25)$ & 0.49 & $36(31-46)-44(39-50.5)$ & 0.09 \\
\hline Çocuğunuza așı yaptırmayı düșünüyor musunuz? & $38.5(34.75-48)-42.5(35.25-47.5)$ & 0.11 & $36(30.5-41.5)-44(38.5-49)$ & 0.45 \\
\hline \multicolumn{5}{|l|}{ Koronavirüs enfeksiyonundan korunmada } \\
\hline $\begin{array}{l}\text { El yıkamanın ne kadar koruyucu olduğunu } \\
\text { düşünüyorsunuz? }\end{array}$ & $42.5(36-50)-40.5(34.75-50.75)$ & 0.21 & $36(32-46.5)-43(37.5-48.5)$ & 0.77 \\
\hline $\begin{array}{l}\text { Sosyal izolasyonun ne kadar koruyucu olduğunu } \\
\text { düșünüyorsunuz? }\end{array}$ & $37.5(34.5-42.5)-44(36-52.25)$ & 0.74 & $36(32-47)-43(37.5-48)$ & 0.51 \\
\hline $\begin{array}{l}\text { Sosyal mesafenin korunmasının ne kadar koruyucu } \\
\text { olduğunu düşünüyorsunuz? }\end{array}$ & $39.5(36.25-46.75)-48(41.25-56.75)$ & 0.31 & $36(32-46)-42(37-47)$ & 0.06 \\
\hline $\begin{array}{l}\text { Maske takmanın ne kadar koruyucu olduğunu } \\
\text { düșünüyorsunuz? }\end{array}$ & $47.5(30-59.75)-49(45.75-53.5)$ & 0.09 & $36(32-42.5)-41(36-46)$ & 0.004 \\
\hline $\begin{array}{l}\text { Koronavirüs enfeksiyonuyla ilgili haberlerde } \\
\text { Sosyal medyanın güvenilir olduğunu düşünüyor } \\
\text { musunuz? }\end{array}$ & $36(30-46)-44(36-50)$ & 0.08 & $38(35.25-49.75)-41(37.25-46.75)$ & 0.44 \\
\hline $\begin{array}{l}\text { Sosyal medya takibiyle bilgi sahibi olduğunuzu } \\
\text { düșünüyor musunuz? }\end{array}$ & $36(32-46)-44(38-46)$ & 0.72 & $37.5(31.25-46.75)-42.5(36-50.5)$ & 0.74 \\
\hline $\begin{array}{l}\text { Koronavirüs hastalığında astımın } \\
\text { Yakalanmada daha riskli olduğunu düşünüyor } \\
\text { musunuz? }\end{array}$ & $37(31.5-45)-42(36.5-46)$ & 0.75 & $36.5(32-47.25)-43(38-53)$ & 0.25 \\
\hline $\begin{array}{l}\text { Tedavisini zorlaştırdığını düşünüyor musunuz? } \\
\text { Hastaneye gelirken toplu taşıma kullanıyorsanız }\end{array}$ & $36.5(31-43.75)-41.5(36-49.5)$ & 0.63 & $37(32-47)-44(38-48)$ & 0.43 \\
\hline $\begin{array}{l}\text { korona virüs bulaşması için ne kadar riskli } \\
\text { buluyorsunuz? }\end{array}$ & 37 (33.25-45.5) - 41 (30.75-49.25) & 0.98 & $37(32-46)-43(38-48)$ & 0.5 \\
\hline
\end{tabular}

DSKE-1 ve DSKE-2: Erişkinler için Durumluk-Sürekli Kaygı Envanteri

COViD-19 enfeksiyonuna kendisinin veya aile bireylerinden birinin yakalanacağını düşünenlerin hem DSKE-1 hem DSKE-2 puanları anlamlı olarak daha yüksek bulundu. Benzer şekilde COVID-19 enfeksiyonunu tedavi eden ilaç ve önleyici aşı bulunacağını düşünenlerin DSKE-1 ve DSKE-2 puanları anlamlı olarak daha düşüktü. Katılan ve katımayanlar arasındaki ayrıntıı karşılaştırma Tablo III'de gösterilmiştir.

\section{TARTIŞMA}

Çocukluk çağının en sık görülen kronik solunum yolu hastalıklarından olan astımlı çocukları değerlendirdiğimiz çalışmamızda hastalarımızın çoğunun astım ilaçlarını düzenli kullandığını ve takiplerine düzenli olarak geldiğini belirledik. Bunun sonucunda da hastalarımızın \%85.1'i çocukluk çağı AKT'ye göre iyi kontrollü astım olarak sınıflandırıld. Ayrıca çocukların Ç-DSKE skorları ile ebeveynlerinin DSKE-1 ve 2 puanları pozitif yönde korelasyon gösteriyordu. Likert ölçeğine göre hazırladığımız COViD-19 enfeksiyonuyla ilgili mini ankette kendisinin veya ailesinden birisinin hastalığa yakalanacağını düşünenlerin DSKE-1 ve 2 puanları düşünmeyenlere göre anlamlı olarak daha yüksek, COVID-19 enfeksiyonuna karşı etkili ilaç ve aşı bulunacağını düşünenlerin DSKE-1 ve 2 puanları, düşünmeyenlere göre anlamlı daha düşük bulundu.

Alerjik hastalıkların tüm dünyada olduğu gibi ülkemizde de sıklığı artmaktadır. Astım, düzenli tedavi ve takip gerektiren, sadece fiziksel değil ruh sağlığını da etkileyen çocukluk çağının en sık görülen kronik hastalıklarından birisidir. Astımın kontrol altında olmaması sadece çocukların değil ailelerin de yaşam kalitesini olumsuz yönde etkiler $(2,25)$.

Son ylllarda astım ve anksiyete, dikkat eksikliği ve hiperaktivite bozukluğu, somatizasyon bozukluğu gibi psikiyatrik hastalıklar 


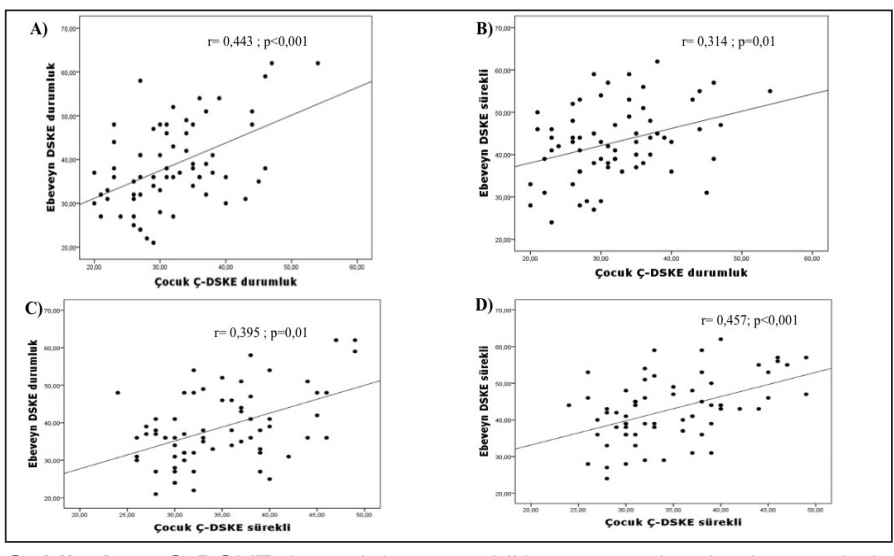

Şekil 1A-D: Ç-DSKE durumluk ve sürekli kaygı puanlarılla ebeveynlerin DSKE durumluk ve sürekli kaygı puanları arasındaki pozitif korelasyon. Ç-DSKE: Çocuklar için Durumluk-Sürekli Kaygı Envanteri. DSKE: Erişkinler için Durumluk-Sürekli Kaygı Envanteri.

arasındaki ilişkiyi araştıran çalışmalar dikkat çekmektedir. Avusturalya'da yapılmıș bir doğum kohortunda astım semptomu olan çocuklarda anksiyete, depresyon, iletișim sorunları gibi psikiyatrik bozuklukların daha fazla eșlik ettiği, ayrıca astım șiddeti ve yetersiz kontrollü olmasıyla da görülme sıklı̆ı̆ının arttı̆̆ı bildirilmiștir. Bu çalıșmanın prospektif olması nedeniyle sonuçları, astım semptomlarının retrospektif olarak değerlendirildiği çalışmalara göre daha güçlüdür (26).

COVID-19 pandemisi çok hızlı bir şekilde tüm dünyaya yayılarak etkisi alıına almıștır. Zorunlu ev karantinaları, sosyal mesafe, pandeminin bașlangıcındaki belirsizlikler, okul ve ișyeri kapanmaları, tüm dünyada insanların sadece fiziksel değil ruh sağıığını da olumsuz yönde etkilemiştir. Özellikle kronik hastalığı olanlarda daha fazla kaygı ve endișeye neden olmuștur. Hastane bașvuruları sırasında virüs bulașma riski insanları tedirgin etmiș, pek çok kronik hastalığı olan birey rutin kontrollerini ertelemiș ve pandemiyle birlikte teletıp yöntemiyle uzaktan sağlık kontrolleri gündeme gelmiştir $(27,28)$.

Genel olarak SARS-CoV-2 enfeksiyonu çocuk ve ergenlerde erișkinlere göre daha hafif seyretmektedi (11). COVID-19 hastalığında solunum yolları öncelikli etkilediğinden astımlı hastalar açısından bir risk oluşturup oluşturmayacağı pandeminin bașlangıcında tartıșma konusu olmuștur. Çalıșmalarda risk açııından farklı sonuçlar bildirilmiștir. Çin'den yapılan ilk yayınlarda astımın ağır COVID-19 hastalı̆̆ıla ilișkisi gösterilememiștir $(29,30)$. Ancak daha sonra Amerika Birleșik Devletleri verilerinde astımın özellikle 18-49 yaș arasındakilerde COVID-19 nedeniyle yatıș için risk olușturabileceği ve bu yaș grubunda COVID-19 nedeniyle hastaneye yatıılan erișkinleri \%27.3'ünde astımın eşlik ettiği bildirilmiştir (31).

Astım atakları çocukluk çağında genel olarak viral üst solunum yolu enfeksiyonlarılla tetiklenmektedir (9). Çocuklarda astım ve COVID-19 ilișkisi arasında kısıtlı sayıda veri bulunmaktadır. SARS-CoV-2 enfeksiyonu konfirme edilmiş olan astımlı çocukların değerlendirildiği çok merkezli bir çalıșmada, astımlı çocukların ve ergenlerin, astım iyi tedavi edildiğinde ve semptomlar kontrol altında olduğunda COVID-19 için ek koruyucu önlemlere gereksinim olmadığı bildirilmiștir (32).

Astımlı çocukların pandemi süresince halihazırda kullanmakta oldukları inhaler tedavilerine devam etmeleri astım kontrolünün sağlanması açısından önemlidir $(33,34)$. Biyolojik ajan kullanan ağır astımlı çocukların da tedavilerine devam etmeleri, sadece aktif koronavirüs enfeksiyonu sırasında klinik düzelme sağlanana kadar biyolojik ajana ara verilmesi önerilmektedir $(35,36)$.

Okulların kapalı olmasının viral enfeksiyon bulașma riskinin azalmasına yol açarak astım semptomları üzerinde olumlu etkisi olabilir. Ülkemizden yapılan hafif-orta astımlı 165 çocuğun astım semptomlarının bir önceki yıl aynı dönemle karșılaștııılığı bir çalışmada, viral solunum yolu enfeksiyonlarının ve hava kirliliğinin azalması sonucunda astım ataklarılla birlikte toplam inhaler steroid kullanımının azaldığı ve astım kontrol testlerinin anlamlı olarak düzeldiği bildirilmiştir (37).

Çalıșmamızda benzer șekilde hastaların çoğunun astım kontrolleri iyiydi, astımlı çocukların çoğu kontrollerine düzenli geliyor ve ilaçlarını düzenli alıyordu. Biyolojik ajan kullanan hastamız bulunmamaktaydı. Hastalarımızın hiçbirinde anket yapılmadan önce COVID-19 geçirme öyküsü olmadığı için COVID-19 ve astım ilișkisini karșılaștırma șansımız olmadı.

121 astımlı ergen hastanın değerlendirildiği bir çalıșmada hastaların yalnızca \%29'unun astımı kontrol altındaydı. $\mathrm{Bu}$ çalışmada astım hastalarında ve ailelerinde kaygı ve depresyonun yaygın olduğu, ayrıca astım kontrolüyle de ilișkili olabileceği belirtilmiștir. Bu yüzden astımlı hastaların klinik takibi yapılırken psikolojik değerlendirilmenin de yapılması önerilmiștir (38).

Benzer șekilde 12-18 yaș astımlı ergenlerde yapılan bașka bir çalışmada astım kontrolü kötü olanların durumluk kaygı düzeyi kontrol altında olanlara göre anlamlı olarak daha yüksek olduğu bildirilmiștir (39). Bizim çalıșmamızda farklı olarak sadece 10 hasta (\%14.9) kontrolsüz astım olarak sınıflandırılmıştı. Buna bağlı olarak Ç-DSKE puanlarında yüksek puanlama görülmedi. Çoğu hastamızın astımı kontrol alıında olduğu için astım kontrol durumuyla Ç-DSKE ve DSKE skorları arasında da bir ilişki saptanamadı.

Çalışmamıza benzer şekilde pandemi öncesinde astımlı çocuklarda yapılmış bir çalışmada iyi kontrolü astımı olanların sağ|lklı akranlarıyla karşılaştııldığında anksiyete ve depresyon semptomları açısından artmış bir risk belirlenememiș, kötü kontrollü astımı olanların yüksek anksiyete ve depresyon semptomlarılyla ilişkili olduğu bildirilmiştir (40).

Çalıșmamızın en önemli kısıtllığı hastaların ve ebeveynlerin anketlere doğru yanıt vermeme olasılıklarının olmasıdır. Özellikle maddi durum ve ilaç kullanımının düzenli olup olmaması konusunda verdikleri yanıtlar hata payımızı artırmıș olabilir. Pandemi öncesi astımlı çocukların anksiyete ve kontrol durumuna göre değerlendirilmemiș olması da diğer bir kısıt|lıktır. Çalışmanın en güçlü yanı ise prospektif olarak yapılıış olmasıdır. 
Astım ve COVID-19 arasındaki ilişkiyi belirlemek için özellikle çocuk yaş grubunda daha fazla çalışmaya intiyaç vardır. Mevcut veriler düzenli ilaç kullanıp astımı kontrol alında olan çocuklarda SARS-CoV-2 enfeksiyonu için ek bir risk olmadığı görüşünü desteklemektedir. Astımlı çocuklar rutin kontrolleri sırasında özelikle pandemi döneminde psikososyal açıdan değerlendirilmeleri çocukların ruh sağlığı ve hastalık kontrolü üzerinde olumlu etkileri olabilir.

Sonuç olarak ebeveyn ve çocuk kaygı düzeylerinin birbirleri ile uyumlu olması ailelerin kaygılarını çocuklarına yansıttıklarının önemli bir bulgusudur. Ebeveynlerin hastalık hakkında olumsuz görüșlerinin olması da kaygı düzeylerini artırmaktadır.

\section{KAYNAKLAR}

1. Dharmage SC, Perret JL, Custovic A. Epidemiology of asthma in children and adults. Front Pediatr 2019;7:246.

2. GINA. Global Initiative for Asthma (GINA): Global strategy for asthma management and prevention. Updated 2020: Available at: http://www. ginasthma.com.

3. Cloutier MM, Baptist AP, Blake KV, Brooks EG, Bryant Stephens T, DiMango E, et al. 2020 Focused Updates to the Asthma Management Guidelines: A Report from the National Asthma Education and Prevention Program Coordinating Committee Expert Panel Working Group. J Allergy Clin Immunol 2020;146:1217-70.

4. World Health Organization Current novel coronavirus (2019-nCoV) outbreak. 2020 https://www.who.int/health-topics/coronavirus.

5. Zhu N, Zhang D, Wang W, Li X, Yang B, Song J, et al. A novel coronavirus from patients with pneumonia in China, 2019. N Engl J Med 2020;382:727-33.

6. Kaushik S, Aydin SI, Derespina KR, Bansal PB, Kowalsky S, Trachtman R, et al. Multisystem inflammatory syndrome in children associated with severe acute respiratory syndrome coronavirus 2 infection (MIS-C): a multi-institutional study from New York City. J Pediatr 2020;224:24-9.

7. Yasuhara J, Kuno T, Takagi H, Sumitomo N. Clinical characteristics of COVID-19 in children: A systematic review. Pediatr Pulmonol 2020;55:2565-75.

8. Grasselli G, Greco M, Zanella A, Albano G, Antonelli, Bellani G, et al. Risk factors associated with mortality among patients with COVID-19 in intensive care units in Lombardy, Italy. JAMA Intern Med 2020;180:1345-55.

9. Satia I, Cusack R, Greene JM, O’Byrne PM, Killian KJ, Johnston N. Prevalence and contribution of respiratory viruses in the community to rates of emergency department visits and hospitalizations with respiratory tract infections, chronic obstructive pulmonary disease and asthma. PloS one 2020;15:e0228544.

10. Parri N, Lenge M, Buonsenso D. Children with Covid-19 in pediatric emergency departments in Italy. N Eng J Med 2020;383:187-90.

11. Dong Y, Mo X, Hu Y, Qi X, Jiang F, Jiang Z, et al. Epidemiology of COVID-19among childrenin China. Pediatrics2020;145:e20200702.

12. Williamson EJ, Walker AJ, Bhaskaran K, Bacon S, Bates C, Morton $\mathrm{CE}$, et al. Factors associated with COVID-19-related death using OpenSAFELY. Nature 2020;584:430-6.

13. Wang C, Pan R, Wan X, Tan Y, Xu L, Ho C, et al. Immediate psychological responses and associated factors during the initial stage of the 2019 coronavirus disease (COVID-19) epidemic among the general population in China. Int J Environ Res Public Health 2020;17:1729.

14. Guessoum SB, Lachal J, Radjack R, Carretier E, Minassian $\mathrm{S}$, Benoit L, et al. Adolescent psychiatric disorders during the COVID-19 pandemic and lockdown. Psychiatry Res 2020:113264.

15. Kaplan A, Price D. Treatment adherence in adolescents with asthma. J Asthma Allergy 2020;13:39-49.

16. Matsunaga NY, Ribeiro MAGdO, Saad IAB, Morcillo AM, Ribeiro $\mathrm{JD}$, Toro AADC. Evaluation of quality of life according to asthma control and asthma severity in children and adolescents. J Bras Pneumol 2015;41:502-8.

17. Ercan ES, Bilaç Ö, Özaslan TU, Ardic UA. Prevalence of psychiatric disorders among Turkish children: the effects of impairment and sociodemographic correlates. Child Psychiatry Hum Dev 2016;47:35-42.

18. Ercan ES, Polanczyk G, Akyol Ardıc U, Yuce D, Karacetin G, Tufan AE, et al. The prevalence of childhood psychopathology in Turkey: a cross-sectional multicenter nationwide study (EPICPAT-T). Nord J Psychiatry 2019;73:132-40.

19. Sekerel B, Soyer O, Keskin O, Uzuner N, Yazicioglu M, Kilic M, et al. The reliability and validity of Turkish version of Childhood Asthma Control Test. Quality Life Res 2012;21:685-90.

20. Liu AH, Zeiger R, Sorkness C, Mahr T, Ostrom N, Burgess S, et al. Development and cross-sectional validation of the Childhood Asthma Control Test. J Allergy Clin Immunol 2007;119:817-25.

21. Ozusta $H$. Turkish standardization, reliability and validity of State-Trait Anxiety Inventory for Children. Turk Psikoloji Dergisi 1995; 10:32-43.

22. Spielberger CD, Reheiser EC. Measuring anxiety, anger, depression, and curiosity as emotional states and personality traits with the STAI, STAXI and STPI. In MJ Hilsenroth, DL Segal (Eds.), Comprehensive handbook of psychological assessment, Vol. 2. Personality assessment 2004;pp. 70-86.

23. Spielberger C, Gorsuch R, Lushene R. State-trait anxiety inventory STAI (Form Y). Redwood City: Mind Garden 1983.

24. Öner N, LeCompte WA. Durumluk-sürekli kaygı envanteri el kitabı: Boğaziçi Üniversitesi Yayınları; 1985.

25. Costa DD, Pitrez PM, Barroso NF, Roncada C. Asthma control in the quality of life levels of asthmatic patients' caregivers: a systematic review with meta-analysis and meta-regression. J Pediat 2019;95:401-9.

26. Goodwin R, Robinson M, Sly P, McKeague IW, Susser ES, Zubrick SR, et al. Severity and persistence of asthma and mental health: a birth cohort study. Psychol Med2013;43.

27. Li S, Wang Y, Xue J, Zhao N, Zhu T. The impact of COVID-19 epidemic declaration on psychological consequences: a study on active Weibo users. Int J Environ Res Public Health 2020;17:2032.

28. Crane SJ, Ganesh R, Post JA, Jacobson NA. Telemedicine Consultations and Follow-up of Patients With COVID-19. Mayo Clinic Proceedings; 2020: Elsevier. p. S33-S4.

29. Zhang JJ, Dong X, Cao YY, Yuan YD, Yang YB, Yan YQ, et al. Clinical characteristics of 140 patients infected with SARS-CoV-2 in Wuhan, China. Allergy 2020;75:1730-41.

30. Guan WJ, Ni ZY, Hu Y, Liang WH, Ou CQ, He JX, et al. Clinical characteristics of coronavirus disease 2019 in China. N Engl J Med 2020;382:1708-20.

31. CDC COVID-19 Response Team. Coronavirus disease 2019 in children-United States, february 12-april 2, 2020. MMWR Morb Mortal Wkly Rep 2020;69:422-6. 
32. Papadopoulos NG, Custovic A, Deschildre A, Mathioudakis AG, Phipatanakul W, Wong G, et al. Impact of COVID-19 on pediatric asthma: practice adjustments and disease burden. J Allergy a Clin Immunol Pract 2020;8:2592-9.e3.

33. Bousquet J, Jutel M, Akdis CA, Klimek L, Pfaar O, Nadeau KC, et al. ARIA-EAACl statement on asthma and COVID-19 (June 2, 2020). Allergy 2021;76:689-97.

34. Gülșah Ș, Mısırlığlu ED. Astımlı Çocuklarda COVID-19 Etkisi. Türkiye Çocuk Hast Derg 2021;15:251-5.

35. Morais-Almeida M, Aguiar R, Martin B, Ansotegui IJ, Ebisawa M, Arruda LK, et al. COVID-19, asthma, and biologic therapies: what we need to know. World Allergy Organ J 2020:100126.

36. Ertuğrul A, Bostanci İ. Çocuklarda Ağır Astım, Biyolojik Tedaviler ve Covid-19 Pandemisinde Güncel Yaklaşımlar. Türkiye Çocuk Hast Derg 2021;15:168-3.
37. Yucel E, Suleyman A, Hizli Demirkale Z, Guler N, Tamay ZU, Ozdemir C. 'Stay At Home': Is It Good Or Not For House Dust Mite Sensitized Children With Respiratory Allergies? Pediatr Allergy Immunol 2021;32:963-70.

38. Licari A, Ciprandi R, Marseglia G, Ciprandi G. Anxiety and depression in adolescents with asthma and in their parents: a study in clinical practice. Monaldi Arch Chest Dis 2019;89. doi: 10.4081/monaldi.2019.1063.

39. Günaydin Nc, Baykal S. Covid-19 Pandemi Döneminde Astım Tanılı Ergenlerde Anksiyete Düzeyinin Değerlendirilmesi. Namık Kemal Tıp Dergisi 2020;8:288-294.

40. Letitre SL, de Groot EP, Draaisma E, Brand PL. Anxiety, depression and self-esteem in children with well-controlled asthma: casecontrol study. Arch Dis Child 2014;99:744-8. 